\title{
VEGETATION COMMUNITIES OF ZION NATIONAL PARK
}

\author{
Kimball T. Harper \\ Department of Botany and Range Science \\ Brigham Young University \\ Provo, UT \\ Stewart C. Sanderson \\ E. Durant McArthur \\ Shrub Sciences Laboratory \\ Intermountain Research Station - U.S. Forest Service \\ Provo, UT
}

\section{Objectives}

The overall objectives of this study are to 1) provide a map of the current vegetation of Zion National Park (ZNP), 2) provide a listing of all vascular plants known for the Park, 3) list all rare, endangered and exotic plant species growing within the Park and describe the distribution and habitat preferences of each as fully as possible, 4) list representative locations for examples of undisturbed stands of each of the major vegetational types, and 5) present our basic field data to the Park on computer disks with software programs that will permit employees to access data files easily and systematically. These objectives are being satisfied through systematic sampling of the vegetation at $1.6 \mathrm{~km}$ intervals. Ideally, the samples should be taken at all section corners using cadastral survey maps, but some remote portions of the park have never been surveyed. As a consequence, we have established a master grid system overlaying the entire Park. Where survey lines do exist our grid system is completely congruent with them. For ease of identifying grid intersection points for data retrieval, we have assigned alphabetical letters to the north-south lines and arabic numbers to the east-west lines. A master map is on file at $\mathrm{ZNP}$ headquarters at Springdale, Utah.

At each grid intersection (or as near to that point as topography will permit), a 0.01 ha sample plot is inventoried using a procedure developed by the Zurich-Montpellier School of Phytosociology. At each plot, a worker lists all species rooted on the plot and assigns a scaled value for foliage coverage (projected crown cover) and sociability (dispersion of individuals) for each species using the form shown as Table 1. Each plot is permanently marked with a steel reinforcing bar at its center (plots are circular in outline), photographed in color, and identified with its grid designation on an aluminum tag secured to the peg at the center of the plot. The stand location is simultaneously recorded on a low level, aerial photography by running a straight pin through the map and circling and properly identifying the grid location of the pin prick on the back of the photograph. Photos and data forms 
Table 1. Example of data form being used for description of vegetation at the 0.01 hectare plots taken at each intersection of the sampling grid. The data reported are from a real site at the location shown.

ZION NATIONAL PARK VEGETATION

BRIGHAM YOUNG UNTVERSTTY

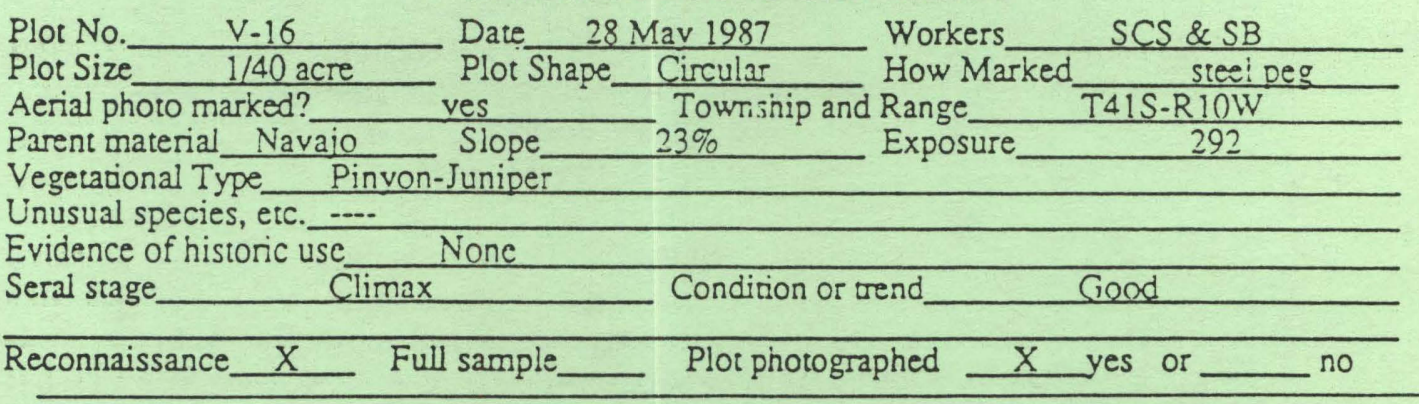

\section{RECONNAISSANCE DATA cover/sociability}

\section{Trees \\ none}

Shrubs

Arctostaphylos patula

Eriogonum

Haplopappus scopulorum

Opuntia macrorhiza

Quercus turbinella

Symphoricarpos longiflora

Yucca angustissima

Graminoids

Oryzopsis hymenoides

Poa fendleriana

Sporobolus cryptandrus

Forbs

Abronia fragrans

Androstephium breviflorum

Arabis perennans

Arenaria fendleri

Chaenactis douglasii

\section{Forbs}

Cryptantha (annual)

Cryptantha cinerea

Delphinium andersonii

Erigeron utahensis

Eriogonum racemosa

Erysimum asperum

flesiny spatulate leaf

Galium triflorum

Gilia inconspicua

Hymenopappus filifolius

Lesquerella rectipes

Lomatium

+1 Machaeranthera canescens

$+1$

$+1$

Orobanche fasciculata

Penstemon laevis

Phlox austromontana

Polygonum douglasii

$+1$

$+1$

$+1$

$+1$

$+1$
Senecio multilobatus

Townsendia montana

Tradescantia occidentalis

Triteleia grandiflora
$+1$

$+1$

$+1$

$+1$

$+1$

$+1$

$\div 1$

$+1$

$+1$

$+1$

$+1$

$+1$

$+1$

$+1$

$+1$

$+1$

$+1$

$+1$

$+1$

$+1$

$+1$

\section{COMMUNITY COVER}

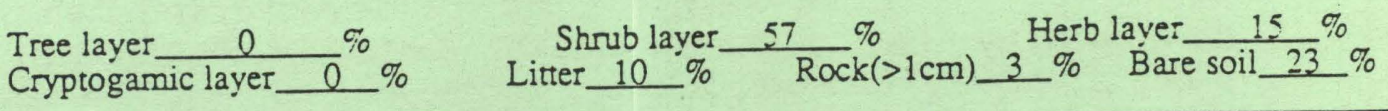

\begin{tabular}{rr}
\multicolumn{2}{c}{ Cover classes } \\
\hline$<1 \%$ & + \\
$1-5 \%$ & 1 \\
$6-25 \%$ & 2 \\
$26-50 \%$ & 3 \\
$51-75 \%$ & 4 \\
$76-95 \%$ & 5 \\
$>95 \%$ & 6
\end{tabular}

Sociability Classes

Growing as single, widely spaced individuals

Small groups

In small patches

Extensive patches

In nearly pure stands 
will ultimately be placed on file at ZNP.

As seen in Table 1 , information concerning geologic substrate, topography, aspect, slope steepness, prior use, and vegetational condition and trend are recorded at each plot. Ultimately, computer files will be accessible using software developed by one of us (SCS) . one will be able to readily obtain printouts showing all locations at which any given species occurs, grid locations of all plots supporting a particular vegetational type, or relative number of exotic versus native species.

\section{Results}

Vegetational Sampling. Our efforts were concentrated in the southeastern third of the Park in the 1987 growing season. In total, over 100 survey plots were read. An additional, 18 samples were taken in the "slick rock" portions of the East Zion Plateau to obtain information about the rock crevice plant communities confined to such environments. These communities have not previously been recognized by science. Preliminary results for the crevice plants are summarized in Table 2.

Uncommon and Exotic Species. Our efforts relative to exotic and rare, threatened, or endangered plant species resulted in collection of 13 plant species previously unknown from $\mathbb{Z N P}$ (Table 3). Our field work also contributed materially to knowledge concerning Sphaeromeria ruthiae, a taxon previously known from only a few (less than 20) individuals. A field expedition was mounted by Drs. McArthur and Sanderson in mid-September 1987 when S. ruthiae, a subshrub confined to crevices in vertical faces of Navajo Sandstone, was in full flower and unusually conspicuous. During a three day period about 900 plants of the species were located in or near ZNNP. New locations within ZNP include populations in Pine Creek Canyon (39 plants), Refrigerator Canyon (78 individuals) and Narrows of the Virgin River at head of Zion Canyon (>112 plants). Populations outside ZNP include 2 in The Barracks area along the East Fork of the Virgin River and east of the southeastern corner of the Park ( $\sim 450$ plants), 1 each in the area of $J$. W. Powell's Plaque (12 ind.), and Parunuweap Canyon just east of the southeastern corner of Park ( 200 ind.), and Orderville Canyon just east of northeastern corner of Park (18 plants).

Other Activity. A manuscript describing the new locations for S. ruthiae has been prepared for submission to a regional botanical journal. One plantlet of the species has been transplanted to the greenhouse in hopes that a reliable chromosome count (not known at present) can be obtained from roottip material.

Field data from the 1987 field season are currently being entered into a computer file. Programs are being written to permit ready access to information in the file. Prior to the 1988 field season, a numerical 
Table 2. Average number of plant individuals per $20 \mathrm{~m}$ length of crevice in the Navajo sandstone, East Zion Plateau, Zion National Park, Utah. The crevice samples are grouped according to potential direct solar beam irradiation as that parameter varies according to slope aspect and steepness.

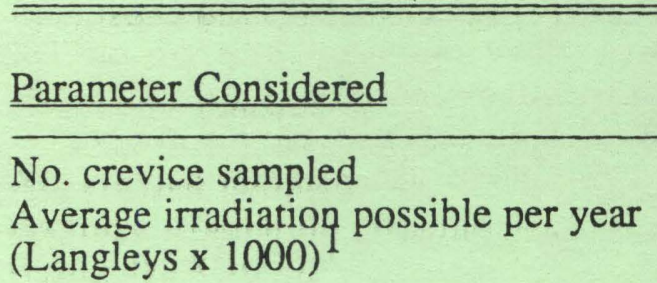

Shrubs

Amelanchier utahensis Arctostaphyllos patula

Cercocarpus intricatus

Eriogonum umbellatum

Holodiscus dumosa

Leptodactylon pungens

L. watsonii

Petrophytum caespitosum

Pinus ponderosa

Other woody plants (9 spp.)

\section{Irradiation Class}

Moderate

6

273.5

301.4

High
179.6

Average No. Plants $/ 20 \mathrm{~m}$

$\begin{array}{lll}0.8 & 0 & 0.5 \\ 0 & 0 & 0.7 \\ 6.7 & 5.8 & 5.2 \\ 1.3 & 0.3 & 0.8 \\ 2.3 & 0.2 & 0.5 \\ 0.2 & 0 & 1.7 \\ 1.7 & 0.5 & 0 \\ 8.0 & 1.0 & 4.8 \\ 1.5 & 0.3 & 0.5 \\ 1.3 & 0.3 & 1.0\end{array}$

Grasses

Andropogon gerardii

Aristida purpurea

Bouteloua curtipendula

Bromus tectorum

Muhlenbergia pauciflora

Poa fendleriana

Other grasses (10 spp.)

$\begin{array}{lll}0 & 0 & 2.7 \\ 0 & 0 & 4.5 \\ 0 & 0 & 1.7 \\ 0 & 1.7 & 0 \\ 4.8 & 4.3 & 2.5 \\ 1.5 & 1.7 & 0.7 \\ 0.7 & 1.3 & 1.2\end{array}$

Forbs

Castilleja scabrida

Erigeron religiosus

Heterotheca jonesii

$\mathrm{H}$. villosa

Ivesia sabulosa

Penstemon barbatus

P. eatonii

Solidago sparsiflora

Senecio spartioides

Stephanomeria tenuifolia

Wyethia scabra

Zauchneria latifolia

Other forbs (11 spp.)

0.8

2.7

2.3

1.3

8.0

0.5

0.0

1.5

0.0

0.7

1.7

0.0

$\underline{2.0}$

0.3

0.7

2.8

0.5

0.2

3.3

0.0

1.5

8.7

0.0

0.2

0.2

2.0

0.0

2.2

6.5

1.2

0.0

1.2

1.0

0.0

Total Individuals $/ 20 \mathrm{~m}$

52.3

0.0

2.7

1.2

1. The Langley is a thermal unit representing 1.0 gram calorie per square centimeter. 
Table 3. Species collected in 1987 in ZNP that were not previously known from the Park.

\begin{tabular}{|c|c|c|}
\hline Family & Genus and Species & Place Collected \\
\hline Boraginaceae & Cryptantha micrantha (Torr.) Johnston & $\begin{array}{l}\text { Head Poverty Wash, } \\
\text { Plot T-16 }\end{array}$ \\
\hline $\begin{array}{l}\text { *Caryophyllaceae } \\
\text { *Compositae } \\
\text { Cruciferae }\end{array}$ & $\begin{array}{l}\text { Stellaria media } \mathrm{L} \text {. } \\
\text { Senecio vulgaris } \mathrm{L} . \\
\text { Draba verna } \mathrm{L} .\end{array}$ & $\begin{array}{l}\text { Grounds at Lodge } \\
\text { Grounds at Lodge } \\
\text { E. end of small tunnel } \\
\text { on Hwy } 15 \text {, E. Zion } \\
\text { Plateau }\end{array}$ \\
\hline $\begin{array}{l}\text { Euphorbiaceae } \\
\text { Hydrophyllaceae }\end{array}$ & $\begin{array}{l}\text { Euphorbia glyptosperma Engelm. } \\
\text { Phacelia cryptantha Greene }\end{array}$ & $\begin{array}{l}\text { Grounds at Lodge } \\
\text { In Mt. brush behind } \\
\text { Zion Lodge }\end{array}$ \\
\hline Leguminosac & Trifolium gymnociarpon Nutt. & $\begin{array}{l}\text { T } 405, \text { R1OW, NE } 1 / 4, \\
\text { Sec. } 1\end{array}$ \\
\hline Polemoniaceae & $\begin{array}{l}\text { Phlox austromontana var. prostata } \\
\text { E. Nels. }\end{array}$ & $\begin{array}{l}\text { Reconnaissance Plot } \\
\text { Q-19 }\end{array}$ \\
\hline $\begin{array}{l}\text { *Gramineae } \\
{ }^{*} \text { Gramineae } \\
{ }^{*} \text { Gramineae }\end{array}$ & $\begin{array}{l}\text { Digitaria sanguinalis (L.) Scop. } \\
\text { Eragrostis cilianensis (All.) Mosher } \\
\text { Festuca bromoides L. }\end{array}$ & $\begin{array}{l}\text { Grounds at Lodge } \\
\text { Watchman Campground } \\
\text { Grounds at Lodge }\end{array}$ \\
\hline$\underline{\text { Family }}$ & Genus and Species & Place Collected \\
\hline $\begin{array}{l}{ }^{*} \text { Gramineae } \\
{ }^{*} \text { Gramineae }\end{array}$ & $\begin{array}{l}\text { Sclerochloa dura (L.) Beauv. } \\
\text { Setaria verticillata (L.) Beauv. }\end{array}$ & $\begin{array}{l}\text { Grounds at Lodge } \\
\text { Watchman Campground }\end{array}$ \\
\hline
\end{tabular}

Asterisked species in the above list are introduced from outside the United States. 
classification analysis will be made of all plot samples of our more common vegetational units in an effort to detect natural subunits within the sample. We are particularly anxious to examine our files for pinyon-juniper vegetation. To date, that is the commonest vegetation type in our file. We will use The Cornell University classification program TWINSPAN to determine whether subsets of the pinyon-juniper data file merit independent recognition. 